\title{
NEINVAZYVIŲ IMPLANTUU STABILUMO TYRIMO SISTEMŲ PALYGINIMAS
}

\author{
Simonas Dvylys, Gintaras Janužis \\ Lietuvos sveikatos moksly universiteto Medicinos akademijos Kauno klinikos
}

Raktažodžiai: osteointegracija, implantų stabilumas, „Periotest“”, „Osstell“, rezonanso dažnio analizè.

\section{Santrauka}

Problemos aktualumas ir darbo tikslas. Implanto stabilumas - labai svarbus faktorius, lemiantis sèkmingą osteointegraciją. Atsižvelgiant ị tai, atsiranda implanto stabilumą matuojančio aparato poreikis. Šio in vitro tyrimo tikslas yra išsiaiškinti ir įvertinti skirtingų neinvazyvių implantų stabilumo vertinimo metodikų „Periotest“ ir „Osstell“ patikimumą bei tikslumą.

Medžiaga ir metodai. Skirtingos morfologinès struktūros jaučio šonkauliuose buvo paruošti dantų alveolių simuliatoriai: nušlifavus kortikalinị kaulą, i spongiozinį kaulą ịpresuoti metaliniai dantų modeliai, kuriuos pašalinus suformuotos alveolès. Pirminès vienmomentinès implantacijos imitacijai panaudoti Megagen AnyRidge 6,0 mm skersmens (kūno skersmuo 4,8mm), 10mm ilgio implantai (Megagen, Gyeongbuk, Pietų Koreja). Implantai įsriegti i jaučio šonkaulyje suformuotas alveolių simuliacijas: 40 implantu, po 20 kieto ir minkšto kaulo grupèse. Kiekvieno implanto pirminio stabilumo matavimai atlikti su „Osstell“" (Integration Diagnostics AB, Savedalen, Švedija) ir „Periotest“ (Gulden Messtechnik, Bensheim, Vokietija) aparatais. Matavimai atlikti meziodistaline ir bukolingvaline kryptimis, kiekviena kryptimi po tris kartus, matavimus atliko vienas tyrejjas. Statistinė duomenų analizė atlikta SPSS 23 versija. Statistinio patikimumo lygis buvo nustatytas $p<0,05$. Rezultatai. Abi sistemos pademonstravo statistiškai patikimus implantų stabilumo tyrimo rezultatus. „Periotest“ ir „Osstell“" vidutiniai rodikliai parode statistiškai reikšmingą skirtumą kieto ir minkšto kaulo grupèse $(\mathrm{P}<0,05)$. „Periotest" aparatas yra labiau jautrus paklaidos galimybei atliekant meziodistalinius matavimus, „Osstell“" aparato rodikliams matavimo kryptis turi mažesnę ịtaką.
Išvados. „Periotest“ ir „Osstell“ sistemos yra statistiškai patikimos matuojant dantų implantų stabilumą. „Osstell“ sistema yra patikimesnè matuojant implantų stabilumą kietame ir minkštame kaule, nei „Periotest" sistema. „Osstell“ sistemai matavimo kryptis turi mažesnę įtaką.

\section{Ivadas}

Gydymas dantų implantais yra sparčiai populiarejjanti ir labai svarbi šiuolaikinès burnos ertmès reabilitacijos dalis. Tačiau net pasitelkus greitai tobulejjančias medicinos srities technologijas ir naujus mokslinius pasiekimus, vis dar pasitaiko gydymo nesėkmių. Vienas pagrindinių sėkmès faktoriu yra implanto stabilumas ir jo palaikymas. Implanto stabilumas yra labai svarbus faktorius, lemiantis sẻkmingą osteointegraciją, kuri yra laikoma tiesiogine struktūrine ir funkcine jungtimi tarp kaulo ir implanto paviršiaus. Implanto stabilumo pasiekimas ir išlaikymas yra labai svarbus faktorius, norint pasiekti sẻkmingą gydymo rezultatą. Todèl implanto stabilumo ịvertinimas ir sekimas ịvairiais gydymo laikotarpiais yra svarbus faktorius, padedantis prognozuoti gydymo sèkmę bei planuoti tolesnius gydymo etapus.

Implanto stabilumas yra pasiekiamas dviem skirtingais etapais: pirminiu ir antriniu. Pirminis implanto stabilumas yra laikomas mechanine jungtimi tarp implanto ir kaulo, $\mathfrak{i}$ kuri ịsriegtas implantas. Pirminis stabilumas priklauso nuo kaulo kokybės, kiekio, chirurginès procedūros tipo, implanto diametro, ilgio ir formos [1]. Antrinis stabilumas susiformuoja ịvykus kaulo regeneracijai ir remodeliacijai apie issriegtą implantą. Antrinis stabilumas priklauso nuo pirminio stabilumo, kaulo formavimosi ir remodeliacijos. Taip pat nuo antrinio stabilumo lygio priklauso implanto apkrovimo protezu laikas. Todèl labai svarbu turèti galimybę ịvertinti implanto stabilumą ivairiais laiko tarpais po implantacijos ir taip nustatyti ilgalaikę gydymo prognozę, atsižvelgiant i esamą implanto stabilumo rodikli.

Šio tyrimo tikslas - išsiaiškinti ir įvertinti skirtingų neinvazyvių implantų stabilumo vertinimo metodikų patikimumą bei tikslumą. Tyrimo uždaviniai: 
1. İvertinti ir palyginti pirminị implanto stabilumą „Periotest" ir "Osstell“" metodais kieto ir minkšto kaulo grupėse.

2. Ivertinti implantu stabilumo vertinimo krypties ịtaką „Periotest" ir „Osstell“ aparatų rodikliams.

3. Nustatyti labiausiai patikimą metodiką bei pateikti rekomendacijas.

\section{Medžiaga ir metodai}

Tyrimo medžiaga ir priemonès. Eksperimentui atlikti naudotas jaučio šonkaulio kaulas. Siekiant imituoti vienmomentę implantaciją ir užtikrinti kuo vienodesnes eksperimento sąlygas, jaučio kauluose buvo paruošti dantų alveolių simuliatoriai: nušlifavus kortikalinị kaulą, ị spongiozinị kaulą buvo ịpresuojamai metaliniai dantų modeliai, kuriuos pašalinus buvo suformuotos alveolès. Eksperimentui suformuotos keturių rūšių alveolių simuliacijos: dvišaknio krūminio danties, trišaknio krūminio danties, dvišaknio prieškrūminio danties, vienašaknio priekinio danties.

Pirminės vienmomentinés implantacijos imitacijai panaudoti Megagen AnyRidge 6,0 mm skersmens (kūno skersmuo 4,8 mm), $10 \mathrm{~mm}$ ilgio implantai (Megagen, Gyeongbuk, Pietų Korëja). Implantai įsriegti ị jaučio šonkaulyje suformuotas alveolių simuliacijas: 40 implantų, 20 implantų kieto kaulo grupeje, 20 implantų minkšto kaulo grupeje. Kiekvienoje grupeje implantuota po 5 implantus ị keturių rūšių alveolių simuliatorius. Implantacijos procedūra atlikta pagal gamintojo nurodytą protokolą.

Atliekant stabilumo matavimus „Osstell“ aparatu, rezonanso dažnio daviklis (27 tipas, Nr. 100431) buvo įsuktas i implantą. Atliekant matavimus „Periotest“ aparatu, buvo naudojama analogiška konstrukcija.

1 lentelè. „Periotest“ ir „Osstell“ matavimo tikslumas kieto kaulo grupeje

\begin{tabular}{|l|c|c|c|c|c|}
\hline Aparatas & $\begin{array}{c}\text { Mata- } \\
\text { vimo ri- } \\
\text { bos }\end{array}$ & $\begin{array}{c}\text { Viduti- } \\
\text { nis ro- } \\
\text { diklis }\end{array}$ & $\begin{array}{c}\text { Stan- } \\
\text { dartinis } \\
\text { nuokrypis }\end{array}$ & $\begin{array}{c}\text { Tarpklasinis } \\
\text { koreliacijos } \\
\text { koeficientas } \\
\text { (ICC) }\end{array}$ & $\begin{array}{c}\text { Tarpklasinio } \\
\text { koreliacijos } \\
\text { koeficiento } \\
\text { intervalas }\end{array}$ \\
\hline $\begin{array}{l}\text { „Periotest“ } \\
\text { (konvertuoti } \\
\text { rodikliai) }\end{array}$ & $1-100$ & 56,5167 & 12,0158 & 0,935 & $0,879-0,971$ \\
\hline „Osstell“ & $1-100$ & 56,1583 & 11,9344 & 0,993 & $0,987-0,997$ \\
\hline
\end{tabular}

2 lentelè. „Periotest““ ir „Osstell“ matavimo tikslumas minkšto kaulo grupejje

\begin{tabular}{|l|c|c|c|c|c|}
\hline Aparatas & $\begin{array}{c}\text { Mata- } \\
\text { vimo ri- } \\
\text { bos }\end{array}$ & $\begin{array}{c}\text { Vidutinis } \\
\text { rodiklis }\end{array}$ & $\begin{array}{c}\text { Stan- } \\
\text { dartinis } \\
\text { nuokrypis }\end{array}$ & $\begin{array}{c}\text { Tarpklasinis } \\
\text { koreliacijos } \\
\text { koeficientas } \\
\text { (ICC) }\end{array}$ & $\begin{array}{c}\text { Tarpklasinio } \\
\text { koreliacijos } \\
\text { koeficiento } \\
\text { intervalas }\end{array}$ \\
\hline $\begin{array}{l}\text { „Periotest“ } \\
\text { (konvertuoti } \\
\text { rodikliai) }\end{array}$ & $1-100$ & 42,1666 & 8,9725 & 0,886 & $0,711-0,955$ \\
\hline "Osstell“ & $1-100$ & 40,8755 & 8,8815 & 0,968 & $0,919-0,987$ \\
\hline
\end{tabular}

Tyrimo eiga. Kiekvieno implanto matavimai buvo atlikti iš dviejų pusių - bukolingvalinès ir meziodistalinès. Kiekvienos krypties matavimas atliktas po tris kartus vienu aparatu, vèliau analogiškai pakartojami matavimai kitu aparatu po tris kartus kiekvienai krypčiai. Atlikus matavimą, eilès tvarka buvo matuojamas kito implanto stabilumas „Osstell““ ir „Periotest“" aparatais, kartojant tą patị protokolą, kol buvo išmatuoti visi implantai abiejose tyrimo grupèse.

Siekiant sudaryti kuo vienodesnes eksperimentines sąlygas, jaučio kaulas buvo issigytas iš to pačio tiekejo. Kiekvienos grupès kaulai tarpusavyje turèjo morfologiškai panašią struktūrą. Kieto tipo kaulai buvo iš distalinių jaučio šonkaulių segmentų. Ši kaulų grupe pasižymėjo morfologija, panašia į 2 grupès kaulo kokybę pagal Lekholm ir Zarb [2], arba D2 - D3 pagal Misch [3]. Minkšto tipo kaulai buvo didesnio diametro, iš proksimalinès šonkaulio dalies. Šios grupès kaulai pasižymėjo mažesniu kiekiu kortikalinio ir didesniu kiekiu spongiozinio kaulo. Šio tipo kaulų morfologija pasižymėjo savybėmis, panašiomis ị 3 kaulo kokybès grupę pagal Lekholm ir Zarb, arba D3 - D4 pagal Misch.

Duomenų statistinė analizè. „Periotest“" ir „Osstell“" matavimų duomenys buvo išnagrinèti statistinès analizès metodu. Statistinio patikimumo lygis buvo nustatytas i $\mathrm{p}<0,05$. Statistiné duomenų analizè atlikta SPSS 23 versija. Tarpklasinis koreliacijos koeficientas buvo skaičiuotas nustatyti kaip tiksliai duomenys atitinka vieni kitus savo grupeje. Tarpklasinio koreliacijos koeficiento ịvertinimas: mažiau nei 0,40 - prastas, nuo 0,40 iki 0,59 - patenkinamas, nuo 0,60 iki 0,74 - geras, nuo 0,75 iki 1 - puikus.

Kronbach'o (Cronbach) alfa rodiklis yra laikomas skalès patikimumo rodikliu, jis parodo, kaip arti vienas kito yra duomenys savo grupeje. Cronbach alfa rodiklio įvertinimas: $\alpha$ mažiau nei 0,5 - nepriimtinas, $\alpha$ rodiklis nuo $0,5 \mathrm{iki}$ 0,6 - prastas, $\alpha$ rodiklis nuo 0,6 iki 0,7 - abejotinas, $\alpha$ rodiklis nuo 0,7 iki 0,8 - patenkinamas, $\alpha$ rodiklis nuo 0,8 iki 0,9 - geras, $\alpha$ rodiklis daugiau už 0,9 - puikus.

Stebèti skirtumai bei priklausomybès tarp požymių buvo laikyti statistiškai reikšmingais, kai apskaičiuotasis reikšmingumo lygmuo (p reikšmė) buvo mažesnis nei pasirinktasis reikšmingumo lygmuo ( $\alpha$ reikšmè).

\section{Rezultatai}

Siekiant palyginti skirtingų aparatų matavimų standartinius nuokrypius „Periotest“ skale (nuo -8 iki 50) buvo konvertuota i „Osstell“ skalę (nuo 1 iki 100) naudojantis matematine lygtimi pagal Lachman'ą (Lach- 
3 lentelè. „Periotest“ ir „Osstell“ matavimo krypties rodiklių tikslumas kieto kaulo grupèje

\begin{tabular}{|l|c|c|}
\hline $\begin{array}{l}\text { Aparatas, mata- } \\
\text { vimo kryptis }\end{array}$ & $\begin{array}{c}\text { Tarpklasinis kore- } \\
\text { liacijos koeficien- } \\
\text { tas (ICC) }\end{array}$ & $\begin{array}{c}\text { Tarpklasinio ko- } \\
\text { reliacijos koefici- } \\
\text { ento intervalas }\end{array}$ \\
\hline $\begin{array}{l}\text { „Periotest" me- } \\
\text { ziodistaliai }\end{array}$ & 0,898 & $0,786-0,957$ \\
\hline $\begin{array}{l}\text { „Periotest" bu- } \\
\text { kolingvaliai }\end{array}$ & 0,925 & $0,841-0,968$ \\
\hline $\begin{array}{l}\text { „Osstell“ mezio- } \\
\text { distaliai }\end{array}$ & 0,999 & $0,997-0,999$ \\
\hline $\begin{array}{l}\text { „Osstell“ buko- } \\
\text { lingvaliai }\end{array}$ & 0,996 & $0,991-0,998$ \\
\hline
\end{tabular}

man) [4]:

„Osstell“" rodiklis $=76-2 \times$, ,Periotest" rodiklis

1-oje lenteleje pateikiami abiejų aparatų matavimo rodikliai ir jų tendencijos kieto kaulo grupèje. 2-oje lentelèje pateikiami analogiški rezultatai minkšto kaulo grupejje.

Matavimo krypties rodikliai ir jų tendencijos pavaizduotos 3 ir 4 lentelèse abiejose kaulo grupèse.

Kieto kaulo grupeje Kronbach'o (Cronbach) alfa rodiklis „Periotest" tyrimo imčiai $\alpha=0,935$. Cronbach alfa rodiklis „Osstell“ tyrimo imčiai $\alpha=0,993$. Minkšto kaulo grupejje Cronbach alfa rodiklis „Periotest“ tyrimo imčiai $\alpha=0,917$. Cronbach alfa rodiklis „Osstell“" tyrimo imčiai $\alpha=0,992$ $(\mathrm{P}<0,05)$.

Vidutinis konvertuotas „Periotest“ rodiklis kieto kaulo grupeje 56,5167, standartinis nuokrypis 12,0158 , minkšto kaulo grupeje šio aparato vidutinis konvertuotas rodiklis 42,1666 , standartinis nuokrypis 8,9725. Vidutinis „Osstell“ rodiklis kieto kaulo grupeje 56,1583, standartinis nuokrypis 11,9344 , minkšto kaulo grupejje šio aparato vidutinis konvertuotas rodiklis 40,8755 , standartinis nuokrypis 8,8815 . Statistiškai reikšmingas skirtumas (naudojant $\mathrm{t}$ - testą) buvo nustatytas tarp kieto ir minkšto kaulo grupių „Periotest“ ir „Osstell“" rodiklių $(\mathrm{p}<0,05)$.

\section{Rezultatų aptarimas}

„Periotest“ ir „Osstell“ sistemos nustatè pokyčius implantų stabilume kietame ir minkštame kauluose, tai ịrodo statistiškai reikšmingas skirtumas $(\mathrm{p}<0,05)$ tarp kieto ir minkšto kaulo grupių rodiklių. Taigi, „Osstell“" sistema šio tyrimo metu parodè patikimesnius rezultatus nei „Periotest“ sistema, lyginant dantų implantų stabilumo rodiklius abiejose kaulo grupėse. Šie tyrimo rezultatai sutapo su 2010 metais Al-Jetaily ir kitų atlikto tyrimo rezultatais [5].

„Periotest" duomenys priklause nuo matavimų krypties. Bukolingvaliniai matavimai demonstruoja didesnį tarpklasinị koreliacijos koeficientą nei meziolingvaliniai $(p<0,05)$. Tai
4 lentelè. „Periotest“ ir „Osstell“ matavimo krypties rodiklių tikslumas minkšto kaulo grupejje

\begin{tabular}{|l|c|c|}
\hline $\begin{array}{l}\text { Aparatas, matavimo } \\
\text { kryptis }\end{array}$ & $\begin{array}{c}\text { Tarpklasinis } \\
\text { koreliacijos } \\
\text { koeficientas } \\
\text { (ICC) }\end{array}$ & $\begin{array}{c}\text { Tarpklasinio } \\
\text { koreliacijos koefi- } \\
\text { ciento intervalas }\end{array}$ \\
\hline $\begin{array}{l}\text { „Periotest“ meziodis- } \\
\text { taliai }\end{array}$ & 0,860 & $0,706-0,940$ \\
\hline $\begin{array}{l}\text { „Periotest“ bukolin- } \\
\text { gvaliai }\end{array}$ & 0,872 & $0,729-0,945$ \\
\hline $\begin{array}{l}\text { „Osstell“ meziodis- } \\
\text { taliai }\end{array}$ & 0,998 & $0,996-0,999$ \\
\hline $\begin{array}{l}\text { „Osstell“ bukolin- } \\
\text { gvaliai }\end{array}$ & 0,993 & $0,986-0,997$ \\
\hline
\end{tabular}

pasireiškia abiejose kaulo grupėse. Tuo tarpu „Osstell“ bukolingvalinių ir meziodistalinių matavimų rodiklių tarpklasinis koreliacijos koeficientas beveik nekito. Tai nustatyta abiejose kaulo grupese $(p<0,05)$. Šie rezultatai sutampa su Bilhan ir bendraautorių 2015 metais atliktu tyrimu [6].

Skirtingi alveolių simuliatorių tipai (dvišaknio krūminio danties, trišaknio krūminio danties, dvišaknio prieškrūminio danties, vienašaknio priekinio danties) tyrimo rezultatams itakos neturejo. Tai parodo aukštas tarpklasinis koreliacijos koeficientas kieto ir minkšto kaulo grupèse, $p<0,05$.

Reikia paminèti, jog abi sistemos turi savų trūkumų, galinčių trukdyti klinikiniame darbe, todèl į juos derètų atsižvelgti. „Osstell“ magnetinio rezonanso dažnio daviklis negali būti ịsuktas ị implantus, turinčius cementuotas protezines dalis, arba jeigu implantų sistema yra sena ir joms jau nebegaminami tinkantys magnetinio rezonanso dažnio davikliai. „Periotest" sistema yra mažiau patogi matuojant galinių dantų grupès implantų stabilumą dèl tiesios aparato lazdelès formos, lyginant su „Osstell“, kurio matavimo zondo forma yra lenkta ir pritaikyta darbui visose burnos ertmès srityse. Mokslo literatūroje yra minima didesnè klaidos tikimybè dirbant „Periotest“ aparatu in vivo sąlygomis palyginus su in vitro sąlygomis [4]. Taip pat šio tyrimo metu buvo pastebèta, jog „Osstell“" aparatas parodo matavimo rezultatą per keletą sekundžių, tuo tarpu „Periotest“ aparato matavimą gali tekti kartoti keletą kartų, kol bus gautas stabilumo rodiklis. Tai gali trukdyti klinikini darbą, užimti per daug laiko ir trukdyti implantų stabilumo tyrimo metodikų naudojimo populiarinimui.

Būtų naudinga atlikti tokio tipo tyrimą įvairiose klinikinėse situacijose, taip patikrinti praktinius šiu aparatų naudojimo aspektus ir patikimumą kasdieniniame gydytojo darbe.

Iš statistikos duomenų galima teigti, jog „Periotest“ ir „Osstell“" aparatai yra patikimi ir priimtini naudojimui, matavimo paklaidos yra ganėtinai mažos, palyginti su pačių mata- 
vimų diapazonu. Taip pat šių aparatų patikimumą pagrindžia aukšti tarpklasinio koreliacijos koeficiento bei Cronbach alfa rodikliai. Šio tyrimo rezultatai parodo, jog „Osstell“" aparatas yra pranašesnis, tačiau abu aparatai gali būti naudojami klinikinèje praktikoje. Taip pat galima įžvelgti „Osstell“ aparato pranašumą dèl patogesnio ir saugesnio prietaiso naudojimo, mažesnès paklaidos tikimybès, šiek tiek geresnių statistinių rezultatų.

\section{Interesų konfliktas}

Autoriams interesų konflikto nebuvo.

\section{Išvados}

1. „Osstell“" sistema yra patikimesnè matuojant implantų stabilumą kietame ir minkštame kaule, nei „Periotest“ sistema.

2. „Periotest“" rezultatus gali sąlygoti specialisto igūdžiai, prietaiso tikslumui didesnę itaką turi naudojimo kryptis - meziodistaliniai matavimai turi didesnę paklaidą. Šios sistemos privalumas yra tai, jog ją naudoti galima nenuimant protezo nuo implanto.

3. „Osstell“" sistemos duomenys mažai priklauso nuo specialisto ịgūdžių, mažesnè paklaidos tikimybè. Prietaiso tikslumui naudojimo kryptis turi mažesnę itaką.

\section{Literatūra}

1. Park J, Lee J, Kim S, Lee J. Implant stability - measuring devices and randomized clinical trial for ISQ value change pattern measured from two different directions. Implant Dentistry 2011; 15:45-51.

http://dx.doi.org/ 10.5772/18309

2. Lekholm U, Zarb GA. In: Patient selection and preparation. Tissue integrated prostheses: osseointegration in clinical dentistry. Quintessence Publishing Company 1985; 199-209.

3. Misch C. Divisions of available bone in implant dentistry. International Journal of Oral and Maxillofacial Implants 1990; 7:9-17.

4. Lachmann S, Jager B, Axmann D, Gomez-Roman G. Resonance frequency analysis and damping capacity assesssment. Part 1: an in vitro study on measurement reliability and a method comparison in the determination of primary dental implant stability. Clinical Oral Implants Research 2006; 1:75-79. http://dx.doi.org/ 10.1111/j.1600-0501.2005.01173.x

5. Al-Jetaily S, Al-Dosari AA. Assessment of "Osstell" and "Periotest" systems in measuring dental implant stability (in vitro study). Saudi Dental Journal 2011; 23:17-21. http://dx.doi. org/10.1016/j.sdentj.2010.09.003

6. Bilhan H, Cilingir A, Bural C, Bilmenoglu C, Sakar O, Geckili $\mathrm{O}$. The evaluation of the reliability of "Periotest" for implant stability measurements: an in vitro study. The Journal of Oral Implantology 2015; 41:90-95.
http://dx.doi.org/10.1563/AAID-JOI-D-13-00303

7. Oh JS, Kim SG, Lim SC, Ong JL. A comparative study of two non invasive techniques to evaluate implant stability: "Periotest" and Osstell Mentor. Oral Surgery, Oral Medicine, Oral Pathology, Oral Radiology and Endodontics 2009; 107:513518. http://dx.doi.org/10.1016/j.tripleo.2008.08.026

8. Zhou C, Yu L, Dong C. The stability analysis of implants installed in osteotomies. Journal of Wuhan University of Technology Mater 2015; 30:210-215.

9. Wentaschek S, Scheller H, Schmidtmann I, Hartmann S, Weyhrauch M, Weibrich G, Lehmann KM. Sensitivity and specificity of stability criteria for immediately loaded splinted maxillary implants. Clinical Implant Dentistry And Related Research 2015; 17:542-549. http://dx.doi.org/ 10.1111/cid.12283

10. Zix J, Hug S, Kessler-Liechti G, Mericske-Stern R. Measurement of dental implant stability by resonance frequency analysis and damping capacity assessment: comparison of both techniques in a clinical trial. The International Journal of Oral and Maxillofacial Implants 2008; 7:17-23.

11. Schnitman PA, Hwang JW. To immediately load, expose, or submerge in partial edentulism: a study of primary stability and treatment outcome. The International Journal of Oral and Maxillofacial implants 2011; 7:20-25.

12. Turkyilmaz I, Sennerby L, McGlumphy EA, Tözüm TF. Biomechanical aspects of primary implant stability: a human cadaver study. Clinical Implant Dentistry and Related Research 2009; 11:113-119. http://dx.doi.org/ 0.1111/j.1708-8208.2008.00097.x

13. Seong WJ, Holte JE, Holtan JR, Olin PS, Hodges JS, Ko CC. Initial stability measurement of dental implants placed in different anatomical regions of fresh human cadaver jawbone. The Journal of Prosthetic Dentistry 2008; 99:425-434.

14. Hsu JT, Fuh LJ, Tu MG, Li YF, Chen KT, Huang HL. The effects of cortical bone thickness and trabecular bone strength on noninvasive measures of the implant primary stability using synthetic bone models. Clinical Implant Dentistry and Related Research 2013; 15:251-261. http://dx.doi.org/ 10.1111/j.1708-8208.2011.00349.x

15. Lachmann S, Laval JY, Jäger B, Axmann D, Gomez-Roman G, Groten M, Weber H. Resonance frequency analysis and damping capacity assessment. Part 2: peri-implant bone loss follow-up. An in vitro study with the "Periotest" and "Osstell" instruments. Clinical Oral Implants Research 2007; 7:80-84. http://dx.doi.org/ 10.1111/j.1600-0501.2005.01174.x

16. Choi HH, Chung CH, Kim SG, Son MK. Reliability of 2 implant stability measuring methods in assessment of various periimplant bone loss: an in vitro study with the Periotest and Osstell Mentor. Implant Dentistry 2014; 23:51-56.

17. Nienkemper M, Wilmes B, Panayotidis A, Pauls A, Golubovic V, Schwarz F, Drescher D. Measurement of mini-implant stability using resonance frequency analysis. The Angle Orthodontist 2013; 83:230-238.

http://dx.doi.org/ 10.2319/043012-354.1 
18. Chang PC, Lang NP, Giannobile WV. Evaluation of functional dynamics during osseointegration and regeneration associated with oral implants. Clinical Oral Implants Research 2010; 21:112.

http://dx.doi.org/ 10.1111/j.1600-0501.2009.01826.x

\section{THE EVALUATION OF NONINVASIVE IMPLANT STABILITY MEASUREMENT SYSTEMS S. Dvylys, G. Janužis}

Key words: osseointegration, Implant Stability, "Periotest", "Osstell", resonance frequency analysis.

Summary

Relevance of the problem and aim of the work. Primary stability at placement of a dental implant is one of the most important factors for a successful osseointegration. Therefore, the need of a reliable implant stability assessment device is required. The aim of this in vitro study was to evaluate reliability of the "Osstell" and "Periotest" devices in the assessment of implant stability and to perform a method comparison.

Material and the methods. The simulators of dental alveolus were prepared into bovine rib segments of different anatomical origins and densities: after removing superficial cortical bone layer, metal teeth models were inserted into spongious bone ant then removed. 40 Megagen AnyRidge 6,0 mm diameter (body diameter 4,8 mm), $10 \mathrm{~mm}$ lenght implants (Megagen, Gyeongbuk, South Korea) were inserted into the simulators of the alveolus to imitate immediate implantation procedure in different bone type groups. The measurements of implant stability were made by "Osstell" (Integration Diagnostics AB, Savedalen, Sweden) and "Periotest" (Gulden Messtechnik, Bensheim, Germany) devices. The measurements were made in mesiodistal and buccolingual directions. Statistical data analysis was made by SPSS 23 version. Statistical significance level was adjusted to $\mathrm{P}<0.05$.

Results. The mean "Periotest" and "Osstell" measurements showed a significant difference between the hard and soft bone groups, $\mathrm{P}<0,05$.

Conclusions. "Osstell" system proved to be more reliable compared to "Periotest" system in measuring dental implant stability in hard and in soft interfaces.

Correspondence to: s.dvylys@gmail.com

Gauta 2017-05-21 